\title{
OWNERSHIP CONCENTRATION AND FIRM PERFORMANCE IN RUSSIA: THE CASE OF BLUE CHIPS OF THE STOCK MARKET
}

\author{
P. KUZNETSOV and A. MURAVYEV
}

(Received: 14 December 2000; revision received: 10 August 2001; accepted: 3 September 2001)

\begin{abstract}
Based on panel data from 1995-1997, the paper focusses on the impact of ownership concentration on the performance of Russian non-financial privatised companies that constitute the group of "blue chips" of the country's stock market. We consider three indicators of company performance - labour productivity, profitability, and Tobins's $q$ - and employ instrumental variables technique to correct regression results for endogeneity of ownership. We find that ownership concentration positively affects labour productivity, but has a negative impact on Tobins's $q$. The relationship between ownership concentration and profitability follows a U-shaped pattern with the turning point at $56 \%$ concentration. These findings imply that ownership concentration results in higher technical efficiency of enterprises, but the benefits from productivity improvements do not accrue to all shareholders. This is consistent with the expropriation hypothesis that large owners use their power to extract private benefits of control.
\end{abstract}

Keywords: concentration, ownership structure, corporate governance, privatisation, Russia.

JEL classification index: C23, D23, G32.

\section{INTRODUCTION}

Ambiguous results of economic reforms in Russia in the 1990s are attributed to many factors among which corporate governance problems seem to play an important role. It was common to blame the privatisation process, which resulted in substantial dispersion of ownership as well as in employee ownership unprecedented by any standard, for poor performance of Russian enterprises. The core problem was seen in the slight involvement of atomistic shareholders-employees in corporate affairs, as well as in the prevalence of particular interests of employees, which prevented or delayed enterprise restructuring. Not surprisingly, con-

Corresponding author: A. Muravyev, Russian-European Centre for Economic Policy (RECEP), Potapovsky per 5 str. 4, 101000 Moscow, Russia. E-mail: amuravyev@recep.ru 
centration of ownership, especially in the hands of outside shareholders, was typically considered as a remedy for inefficiencies emerging in the course of privatisation. This was consistent with the standard approach to corporate governance, which originated in the Berle and Means' analysis of modern corporations.

Post-privatisation developments in the Russian corporate sector, however, make us doubt the correctness of the supposition that ownership concentration and especially concentration in "outside" hands - is beneficial in the Russian context. On the one hand, there are many success stories with companies that obtained majority shareholders, especially from abroad. On the other hand, there is extensive evidence, sometimes anecdotal, on the behaviour of large shareholders, which is directed towards extraction of private benefits of control rather than restructuring of production and improving economic efficiency. Despite close attention to the field of corporate governance in Russia, the issue of whether ownership concentration contributes to the revitalisation of Russian firms has not been directly addressed in the empirical literature. This article intends to fill this gap by studying the effect of ownership concentration on company performance using a sample of the "blue chips" whose shares were traded in the stock market prior to the 1998 crisis.

\section{OWNERSHIP CONCENTRATION AND FIRM PERFORMANCE: A THEORETICAL OVERVIEW}

\section{Traditional approach to corporate governance}

Consequences of ownership structure for corporate efficiency and performance have been in the focus of scientific debate during the last 70 years, after Berle and Means published their famous work (1932). Since the 1970s, this issue has been usually analysed in the context of principal-agent relationships between shareholders and managers. In corporations, the agency relationships typically, though not necessarily, emerge as a result of diffusion of ownership when numerous small owners are incapable of running their firm collectively and have to transfer their rights of control to a special subject of governance, i.e. to the management team.

In terms of the agency theory, separation of ownership and control gives rise to agency costs that worsen performance of companies. Since the interests of managers (agents) need not and normally do not coincide with those of owners (principals), there is considerable risk that corporate resources will not be used in the pursuit of shareholder profit. As a result, corporate shareholders are in need of reliable means of control over managerial behaviour. 
There are four basic control forces bearing on the corporation that act to bring about coincidence of managers' decisions with those that are optimal from a shareholders' standpoint. They are the capital markets, the legal and regulatory system, the product and factor markets, and the internal control system (Jensen, 1997). The latter provides participation of shareholders in corporate governance through election and representation in the boards of directors and serves as the most direct mechanism by which shareholders can influence management. However, the efficacy of this mechanism is limited under diffuse ownership structures when the improvement of corporate governance is a public good for every small shareholder. Due to free-riding of small owners, managers face little restraints and can easily use their discretion for pursuing their own objectives. These may include expropriation of investors' funds, building an empire, or simply living an easy life. After Berle and Means' analysis it has been common to state that dispersed shareholders are "powerless" in the face of managerial opportunism.

According to this line of reasoning, concentration of ownership is a straightforward way to mitigate agency problems between owners and managers. The literature on corporate governance says that large owners have stronger incentives and better opportunities to exercise control over managers than small shareholders do. Moreover, some scholars argue that most corporate governance mechanisms used in the world can be viewed as examples of concentrated ownership (Shleifer and Vishny, 1997).

To summarise, the traditional approach views the main corporate governance problem as the opposition of self-interested managers and weak dispersed shareholders.

\section{Modern perspective on corporate governance}

In recent years, the concept of corporate governance underwent substantial changes. They were evoked by the fact that the widely held corporation, which was the focus of the corporate governance literature, is a rare phenomenon, except for a few countries with common law origin (Bergloef and von Thadden, 1999). In the rest of the world, including most European countries, relatively concentrated ownership prevails. In companies with concentrated ownership, managers are no longer able to act at their own discretion and are constrained to devising company strategies that are subject to non-transparent obligations, which large blockholders impose on them. As a result, the framework of corporate governance enlarges to embrace tangled relationships between managers, large blockholders, and minority shareholders. 
This new framework introduces substantial complexity in the analysis of ownership-performance relationship. In particular, it becomes clear that concentrated ownership has its costs. They may arise when large shareholders, capable of directly influencing corporate decisions, maximise value for themselves and deprive small owners of their part of residual income. This phenomenon has received much attention in the literature under the name of "extraction of private benefits of control" (e.g., Barclay and Holderness, 1989). To the extent these private benefits of controls are pecuniary (as is the case, e.g., with transfer pricing), corporate performance deteriorates. Negative consequences of ownership concentration can also manifest themselves in raised costs of capital due to lower market liquidity or decreased diversification opportunities on the part of investors (Fama and Jensen, 1983). Holmstrom and Tirole (1993) point out that concentrated ownership prevents additional monitoring of managers by the stock market while diffuse ownership, which is characterised by higher liquidity of shares, promotes such monitoring. Some recent studies show that too high concentration of ownership may lead to excessive monitoring, which in turn can reduce managerial initiative. This initiative is not necessarily considered harmful; in fact, it can be beneficial as it induces managers to make firm-specific investments (Burkart et al., 1997). Hence, there is a trade-off between monitoring gains obtainable through outside ownership concentration and potential benefits from providing managers with some discretion through more diffuse ownership structures.

To summarise, the traditional approach, which focusses on protection of minority shareholders from managerial opportunism, is now under fire as "too narrow". Its deficiencies are particularly obvious in applications to developing and transition countries where large strategic investors are the major players on the corporate governance scene (Bergloef and von Thadden, 1999).

Recent literature on corporate governance also pays much attention to the issue of shareholder identity. It stresses that the objective functions and the costs of exercising control over managers vary substantially for different categories of owners. The implication is that it matters not only how much equity a shareholder owns, but also who is this shareholder - a private person, an employee, a financial institution or a non-financial enterprise.

For example, managerial ownership can have ambivalent effects on firm performance. On the one hand, it is considered as a tool for alignment of managerial interests with those of shareholders. Substantial ownership by managers provides them with incentives to maximise profit and thus positively affects firm performance (Jensen and Meckling, 1976). On the other hand, larger ownership by managers promotes their entrenchment, which is especially costly, when they have low qualification or prefer to live an easy life (Morck et al., 1988; Stulz, 1988). The overall impact of managerial ownership on corporate performance depends 
on the relative strengths of these two effects and may exhibit a non-monotonic pattern.

Employee ownership has long been considered a bad idea by Western economists who study corporate governance (Frydman and Rapaczynski, 1994). It is generally agreed upon that the establishment of reliable control over managers on the part of employees is a difficult task (Hansmann, 1990). However, the impact of employee ownership on firm performance can hardly be squeezed into the framework of the theory that focusses on the conflict between owners and managers. For example, employee ownership can resolve or mitigate the classical conflict between labour and capital by entitling employees to a part of company profits. Even when the direct incentive effect of employee ownership is negligible, there may be some gains due to mutual monitoring among employees.

Consequences of outside ownership for firm performance depend on the degree to which outsiders are able to monitor and control managers. It is assumed that concentration of outside ownership increases the likelihood that such control will be exercised. However, the effect of ownership concentration in the hands of outside owners on company performance is not necessarily continuous. Much depends on the distribution of control, which may be different from the distribution of ownership.

With regards to evaluation of state ownership, there is much more unanimity in the academic circles. During the last two decades, state ownership has been usually regarded as inefficient. Deficiencies of state ownership stem from the lack of incentives (Vickers and Yarrow, 1988), price policy (Shapiro and Willig, 1990), political intervention (Shleifer and Vishny, 1994) and human capital problems (Krueger, 1990).

The above theoretical overview indicates that the existing theories generally fail to provide unambiguous predictions about the impact of ownership concentration on company performance. As a result, this issue has recently become the subject of numerous empirical investigations.

\section{EMPIRICAL EVIDENCE}

The impact of ownership concentration on the performance of companies in developed countries has been studied by a number of scholars including Demsetz and Lehn (1985), Zeckhauser and Pound (1990), McConell and Servaes (1990) and Edwards and Weichenrieder (1999). In developing and transition countries, the relationship between ownership and company performance has been investigated among others by Xu and Wang (1997), Earle (1998), Claessens and Djankov (1999), Brown and Earle (2000) and Kapelyushnikov (2000). 
Demsetz and Lehn (1985) use cross-sectional regression of accounting rate of return on a number of variables reflecting ownership concentration (the percentages of shares controlled by the top five and the top 20 shareholders, and the Herfindahl index of ownership concentration). They report no statistically significant relationship between profitability and ownership concentration and suggest that this finding confirms that the existing ownership structures have been optimised in the natural selection process.

McConell and Servaes (1990) investigate the link between ownership structure and the value of the firm measured by Tobins's $q$. They distinguish between several ownership types including the stake of insiders (directors), the stake of institutional investors, and the one of large outside blockholders (not represented in the board of directors). They find a reversed U-shaped relationship between Tobins's $q$ and the shareholdings of insiders. Besides, they report a positive relationship between Tobins's $q$ and the fraction of stock owned by institutional investors.

Zeckhauser and Pound (1990) find that large shareholders, who are interested in monitoring, exert positive influence on the performance of firms with low levels of specific capital (firms with low R\&D-sales ratio). In such firms, the presence of owners wielding over $15 \%$ of stock has a positive and significant effect on the price-earnings ratio. This implies abnormal expected growth of future earnings for such companies.

Edwards and Weichenrieder (1999) investigate the effect of large shareholdings on the wealth of minority investors in Germany. They report that the two beneficial effects associated with the presence of large shareholders, namely better monitoring of management and reduced incentives to exploit minority owners outweigh the harmful effects connected to the extraction of greater private benefits of control.

$\mathrm{Xu}$ and Wang (1997) examine the ownership-performance relationship for a sample of Chinese publicly listed companies. They document a positive and significant correlation between ownership concentration and profitability, the importance of large institutional shareholders in corporate governance, and inefficiency of state ownership.

Earle (1998) examines the impact of ownership structure on the performance of Russian firms soon after the conclusion of voucher privatisation in 1994. The author uses labour productivity as a measure of company performance and employs a two-stage instrumental variables estimation to correct regression results for endogeneity of ownership. He reports a positive impact of outside ownership and ownership by managers on firm productivity. This paper, however, focusses on the impact of various types of ownership on company performance and does not directly study the effect of ownership concentration. 
Using a cross-section of 706 Czech firms over the period of 1992-1997, Claessens and Djankov (1999) find that more concentrated ownership is associated with higher profitability and labour productivity. These findings are weakly robust to the inclusion of control variables for the type of ownership or to the correction for endogeneity of ownership concentration.

Brown and Earle (2000) use an extensive panel dataset on Russian firms from 1993-1998 covering $82 \%$ of industrial employment in 1993 . They find that the best performers are municipally owned firms, which are followed by firms with mixed (state and private) ownership, regionally and federally owned firms, joint ventures and $100 \%$ private firms. Among private ownership types, firms with greater insider stake and shares sold at voucher auctions have performed significantly worse while firms with holding company shares, foreign shares and golden shares have performed better. It is worth noting that this paper, like the above-cited one by Earle (1998), does not explicitly address the ownership concentration issue.

A paper by Kapelyushnikov (2000) is among the few studies that focus on the relationship between ownership concentration and company performance in Russia. The author uses data from three surveys by Russian Economic Barometer conducted in 1995, 1997, and 1999 and finds a non-linear relationship between ownership concentration and company performance: the best performing firms have moderate ownership concentration measured by the stake of their largest shareholders. However, this conclusion may be questioned as the author uses a simple methodology omitting important control variables and disregarding the issue of endogeneity of ownership.

\section{STUDY OBJECTIVE, DATA AND METHODOLOGY}

The objective of this article is to provide empirical evidence on the impact of ownership concentration on the performance of Russian privatised enterprises that constitute the group of "blue chips" of the country's stock market. We confine our analysis to publicly traded companies for several reasons. First, most of these enterprises are large and have substantial impact on the Russian economy. Second, significant dispersion of ownership, which is typical of large companies, calls for a special attention. Last but not least, by studying traded companies one faces less severe data problems as ownership and financial information about these firms is relatively easy to obtain.

This article offers a contribution to the debate on ownership concentration in Russia, avoiding several shortcomings of the previous studies. A bulk of the existing empirical evidence comes from data collected at the time of privatisation or the early post-privatisation period. The findings from these studies can be ques- 
tioned, as it is unclear whether advantages of various ownership structures could be realised within a short period after privatisation of firms. Moreover, by dealing with data from 1993-1994, a researcher faces large incidence of residual state ownership, which makes it problematic to investigate the effect of ownership concentration as it is traditionally perceived in corporate governance studies, that is, concentration of private ownership. Therefore, by using more recent post-privatisation data from 1995-1997, we may obtain more sound conclusions. From the pure technical viewpoint, the study differs substantially from many previous papers as it is based on panel data and employs instrumental variables technique to correct regression results for endogeneity of ownership.

\section{Data and sample description}

We have data on Russian companies compiled from the "blue chips" database of the Skate Financial Press Agency. The original database contains financial and ownership information for 236 firms, whose shares were traded in the stock market in 1997-1998. From this list we excluded companies belonging to the financial sector, newly created firms, as well as firms with no established secondary market for their shares by the end of 1995, 1996, and 1997. In addition, we excluded several firms for which financial and ownership information in 1995-1997 was inaccessible and two companies - Gazprom and Unified Energy Systems -, which, being virtually states within the state, have a very special position in the Russian economy. In some cases, the data from Skate Press were supplemented with information from the Federal Commission for the Securities Market web-site, Gnosis and AK\&M databases, Brunswick Brokerage's Russian Equity Guide Yearbook, and the Russian financial press. The resulting database contains key financials, employment, capitalisation and ownership data for 101 Russian companies. The sample is representative of the population of publicly traded companies in Russia, but this by no means indicates that the sample is representative of the whole population of Russian privatised firms. There are several important characteristics of the sampled companies, which differentiate them dramatically from the "average" privatised enterprise in Russia. The most important differences are observed in the methods of privatisation; they are briefly described below.

Privatisation of the sampled companies differs substantially from the general picture observed in Russia. First, even at the moment of privatisation, the companies had substantially smaller insider ownership compared to the "average" privatised enterprise. The reason is that many of them are large and extra-large capi- 
tal-intensive companies in which insiders were incapable to accumulate enough funds to buy $51 \%$ of shares under the so-called second variant of privatisation, the most generous to insiders. Instead, insiders had to follow the first variant that provided them with much smaller ownership stakes.

Second, the sample is characterised by substantial ownership by the state and various state-controlled holdings. After initial distribution or sale of shares to employees, further privatisation of most Russian enterprises was conducted through voucher auctions, money auctions or investment contests. In contrast to that, a lot of the sampled companies were privatised through the transfer of shares remaining at state disposal to some holding company, which could either remain state-controlled or undergo privatisation in subsequent years. In other words, privatisation of some of the companies was conducted outside the market and was determined by political decisions. In most cases, holding companies became the owners of controlling blocks of shares, accumulating over $51 \%$ of voting stock. Such "holding privatisation" was implemented in 48 companies - about half of the sampled firms. Among them, 36 companies were partly owned by some state-controlled holdings at the beginning of 1997. Besides, minority blocks of shares of several other firms were also transferred to these holdings. In 1997, the holdings had minority ownership stakes in six companies included in the sample.

"Holding privatisation" was typical of companies in the telecommunication and electric power sectors, as well as in the oil extraction and processing industry. It should be pointed out that a large number of companies privatised through this method is not a specific characteristic of the sample; rather, it is peculiar to the majority of Russian firms that are traded in the country's stock market. The last remark with respect to privatisation of the sampled companies is that six of them went through the famous "loans-for-shares" scheme in 1995.

\section{Indicators of firm performance}

The concept of firm performance can be interpreted in several different ways (Bevan et al., 1999). Performance may be associated with technical efficiency of production for which total factor productivity is the best indicator. However, total factor productivity is not widely used in empirical studies due to difficulties in measuring capital stock. Most empirical papers focus instead on labour productivity, profitability, output growth, and Tobins's $q$, which is defined as the ratio of the market value of company to the replacement value of its assets.

Measurement of enterprise performance in transition economies faces additional complications, which primarily stem from high inflation rates and changes 
in accounting standards. Distortions can also arise due to arbitrariness of pricing when firms use barter or other non-monetary forms of payment, which is widespread in many transition countries.

In this study we consider three measures of firm performance, namely labour productivity, profitability and Tobins's $q$. This choice is motivated by the assumption that these performance indicators may have different interpretations as characterising different aspects of company operations. For example, labour productivity can be interpreted as a measure of enterprise efficiency, which refers to the technological dimension of firms. Unlike labour productivity, Tobins's $q$, which is calculated on the basis of share prices, reflects company value for small shareholders. Though there is an obvious connection between these two performance measures (labour productivity improvements should be reflected in higher prices of shares, and, consequently, higher Tobins's $q$ ), the latter indicator reflects other significant factors, for example, the risk of expropriation of small shareholders by large owners. The value of a company with high labour productivity (or technical efficiency in general) may be low if large shareholders appropriate the lion's share of company profits using transfer pricing or similar techniques.

We calculate labour productivity as the ratio of sales revenues excluding VAT and excises (all adjusted for inflation) to the year-average number of employees. Profitability is defined as gross profit (net of interest and depreciation, but gross of taxes) over the book value of equity at the year-end (all adjusted for inflation). Due to substantial discrepancies between the market value of debt and the value of debt in the balance sheets of Russian companies, the traditional market-to-book proxy for Tobins's $q$ is not used. Following Perotti and Gelfer (1998), Tobins's $q$ is approximated by the ratio of the market value of equity to the book value of equity. To calculate Tobins's $q$ we use unadjusted year-end values of these parameters. Descriptive statistics for the above-mentioned performance measures are shown in Table 1.

Table 1

Descriptive statistics for performance indicators*

\begin{tabular}{lllll}
\hline & & 1995 & 1996 & 1997 \\
\hline Labour productivity, & Mean & 0.2272 & 0.2119 & 0.2209 \\
mln RUR per employe** & St. dev. & 0.1677 & 0.1482 & 0.1491 \\
Profitability* & Mean & 0.1436 & 0.0870 & 0.0710 \\
& St. dev. & 0.1636 & 0.1511 & 0.1334 \\
Proxy for Tobins's $q^{* *}$ & Mean & 0.0856 & 0.2314 & 0.5025 \\
& St. dev. & 0.1274 & 0.4105 & 0.5810 \\
\hline
\end{tabular}

* Calculated after adjusting company financial data for inflation, December, 1997 prices.

** Calculated using unadjusted values of the market value of equity and the book value of equity. 


\section{Indicators of ownership concentration}

Due to the absence of detailed ownership data in the Skate dataset, we created two simple indicators of ownership concentration. The first one measures ownership concentration as the percentage of voting shares in the hands of the top three shareholders without drawing distinction between different groups of owners (the variable cons_overall). As various state-controlled holdings and the state itself are large shareholders in many of the sampled firms and their objective functions and behaviour can be different from those of private investors, the second indicator (the variable conc_private) is defined as the percentage of voting shares in the hands of the top three investors, which are not related to the state. It is important to note that our definition of ownership variables is rather mechanical and fails to take into account possible ties between shareholders in any given company. If two shareholders are closely related to each other, for example, a part of one industrial group, we count them as two separate entities. For that reason our measures of ownership concentration may contain a downward bias.

Descriptive statistics for the above-mentioned ownership variables as well as for two additional ones measuring ownership by the state and state holdings are shown in Table 2. Except for ownership by state holdings, all variables show significant variation in time.

Table 2

Descriptive statistics for ownership variables (\%)

\begin{tabular}{llcrr}
\hline & & 1995 & 1996 & 1997 \\
\hline State & Mean & 12.8 & 6.9 & 6.6 \\
(state ownership) & St. dev. & 18.6 & 12.6 & 13.0 \\
State_hold & Mean & 22.6 & 20.3 & 20.7 \\
(ownership by state-controlled holdings) & St. dev. & 26.6 & 26.4 & 26.4 \\
Conc_overall & Mean & 53.3 & 56.7 & 60.9 \\
(the top three shareholders) & St. dev. & 18.2 & 17.4 & 16.8 \\
Conc_private & Mean & 20.1 & 31.5 & 36.1 \\
(the top three state-unrelated shareholders) & St. dev. & 15.1 & 22.3 & 23.1 \\
\hline
\end{tabular}

\section{Econometric model}

We estimate parameters of the model, which in general form can be written the following way:

$$
\operatorname{Perf}_{i t}=\alpha_{i}+\beta_{1} \operatorname{conc}_{i t}+\beta_{2} \operatorname{conc}_{i t}^{2}+\sum_{k} \gamma_{k} Z(k)_{i t}+\varepsilon_{i t},
$$


where $\operatorname{Perf} f_{i t}$ is one of the selected performance measures, conc $_{i t}$ is a variable reflecting ownership concentration, $Z(k)$ is the component number $k$ of the vector of control variables, $\alpha_{i}$ refers to time-invariant firm-specific effects, and $\varepsilon_{i t}$ is a random disturbance.

We use quadratic specification of the regression equation to account for possible non-linearity of the relationship between firm performance and ownership concentration. As mentioned in the theoretical overview, the existing theories of corporate governance assume both benefits and costs of ownership concentration, which implies that company performance may be, for example, a non-linear monotonically increasing function of concentration or there may be an "optimal" level of ownership concentration. Control variables are standard for this type of analysis and include five dummies for the basic industries and a measure of size, which is approximated by the logarithm of employment in 1994.

It is widely known that in 1995-1997 the Russian enterprises enjoyed large inflation-generated profits, which stemmed from undervaluation of accounted costs of production relative to actual sales revenues when there was a noticeable change in price levels. To control for these "paper" profits in the regression equations with profitability we include a special variable that reflects inflation rates between 1995-1997. Similarly, an additional variable equal to the logarithm of the value of the Russian Trading System (RTS) index is included in the equations with Tobins's $q$ to control for the growth of the stock market during the period. This growth was stimulated primarily by changes in the institutional and macroeconomic environments rather than by improvements in the performance of companies.

The models are estimated using a random effects approach. This is done for two reasons. First, some scholars argue that a random effects approach should be used unless there is a good reason to avoid it (e.g., Mundlak, 1978). Second, for a short panel and explanatory variables with low variation (as is the case with ownership variables) using a fixed-effects approach will result in only a handful of firms driving the results for regressors. Besides an improper estimation of the coefficients, the endogeneity problem, which is discussed below, may be more severe in this case.

\section{Endogeneity problem}

Analysis of the impact of ownership on firm performance often relies on the implicit assumption that ownership structure is exogenous, that is, not affected by performance itself. This assumption, however, can be questioned in many ways. The most evident case of reversed causality in the ownership-performance rela- 
tionship is connected with managerial ownership, which is directly influenced by firm performance if managers receive compensation in the form of equity. For ownership structures that emerge during a transition period, the endogeneity problem may be especially severe. Different interest groups might try to select better firms for their investments, and this selection may be expected on the part of both outside investors and insiders. The proper treatment of the endogeneity problem is of great importance as it prevents researchers from obtaining biased estimates in regression analyses.

As applied to our dataset, a part of the ownership variables can be considered as exogenous and the other part as being subject to endogeneity. The first group embraces state ownership and ownership by state holdings. We believe that after the conclusion of mass privatisation they were determined by political rather than by economic factors (i.e., they were hardly influenced by company performance). In particular, the decision to transfer state blocks of shares to holding companies looks as politically motivated. In addition, one can wonder if the decision to "freeze" large blocks of shares of some companies in state ownership had an economic rationale rather than a political one.

The picture is less clear concerning the other ownership variables. On the one hand, all the above-mentioned arguments about endogeneity hold. On the other hand, owing to "holding privatisation" ownership concentration can be regarded as to a large extent imposed on the firms rather than determined by the market. Also, the effect of selection of better enterprises on the part of investors may be rather small - all the sampled enterprises form a relatively homogenous group of "blue chips" of the stock market. Besides, the dataset is constructed in such a way that additionally reduces the scope of the problem. All the ownership variables contain records referring to the beginning of each year and thus may be correlated with firm performance in the previous, but not in the current year. In other words, with respect to the performance measures the ownership variables contain lagged values.

These reservations are nevertheless not sufficient to claim that the ownership variables are exogenous. Therefore, we employ instrumental variables (IV) technique and use the error component two stage least squares (EC2SLS) estimator developed by Baltagi (1995). All the instruments we use can be classified in three groups. The first group contains instruments that characterise firm privatisation particularities. They include a dummy for the second variant of privatisation, a dummy for "loans-for-shares" privatisation, a dummy for "holding privatisation", and a variable reflecting time elapsed after privatisation (in months). The second group instruments refer to the economic and social conditions in the regions in which the sampled enterprises are located. This group contains variables reflecting relative position of regions with respect to such factors as the development of 
market economy institutions, investments, overdue receivables of regional enterprises, the share of loss-making firms, the development of small business, and the crime rate. The third group embraces two variables indicating the relative positions of industries with respect to overdue receivables and output decline.

\section{STUDY RESULTS}

Two specifications are used to investigate the effect of ownership concentration on firm performance. In the first specification, there is no distinction between different types of owners; concentration is measured in a rather mechanical way using variable conc_overall (the stake of the top three shareholders). Regression results for the three specified dependent variables are reported in Table 3.

Table 3

Concentration of ownership and firm performance - IV estimation

\begin{tabular}{|c|c|c|c|c|c|c|}
\hline & \multicolumn{2}{|c|}{ ln (labour productivity) } & \multicolumn{2}{|c|}{ profitability } & \multicolumn{2}{|c|}{$\ln$ (Tobins's $q$ ) } \\
\hline & Coef. & $\mathrm{z}$ & Coef. & $\mathrm{z}$ & Coef. & $\mathrm{z}$ \\
\hline conc_overall & $.0098235 * *$ & 2.14 & $-.0207848 * *$ & -2.55 & $-.1516202 * *$ & -1.97 \\
\hline conc_overall_squared & & & $.0001855^{* * *}$ & 2.60 & $.001224^{*}$ & 1.82 \\
\hline metallurgy & .1452791 & 0.74 & -.0373763 & -0.76 & $-.7173452 *$ & -1.67 \\
\hline machine building & $-.978368 * * *$ & -4.82 & $-.0878735^{*}$ & -1.73 & $-1.381342 * * *$ & -3.13 \\
\hline oil, gas and chemicals & .3102374 & 1.37 & -.0326654 & -0.52 & .0267061 & 0.05 \\
\hline power utilities & $.5193694 * *$ & 2.14 & -.0156326 & -0.23 & -.288405 & -0.48 \\
\hline telecommunications & $-.7863507 * * *$ & -3.41 & .0651104 & 0.98 & $1.242237 * *$ & 2.10 \\
\hline size & $-2.116004 * * *$ & -3.53 & $-.250663^{*}$ & -1.66 & -2.011259 & -1.53 \\
\hline size squared & $.1084279 * * *$ & 3.43 & .0127297 & 1.61 & .1065716 & 1.55 \\
\hline dummy for 1996 & -.0573525 & -1.51 & .0962745 & 0.93 & $-.7457243 * * *$ & -4.37 \\
\hline dummy for 1997 & -.0471946 & -1.13 & .089011 & 0.87 & $-.7239872 * * *$ & -4.31 \\
\hline inflation & & & .001221 & 1.32 & & \\
\hline ln (RTS index) & & & & & $1.653209 * * *$ & 11.59 \\
\hline constant & $8.003193 * * *$ & 2.83 & $1.714483^{* *}$ & 2.27 & 3.503849 & 0.57 \\
\hline Wald chi2 & 147.37 & & 97.53 & & 511.36 & \\
\hline Prob $>$ chi 2 & 0.0000 & & 0.0000 & & 0.0000 & \\
\hline
\end{tabular}

$* * *$ significant at $1 \%$ level, $* *$ significant at $5 \%$ level, * significant at $10 \%$ level

Note: The variable conc_overall_squared is dropped when the coefficients on it and the variable conc_overall are both insignificant while their joint significance is not rejected at $\mathrm{p}=0.05$.

As follows from Table 3, ownership concentration among all categories of owners has a positive linear impact on labour productivity; the result is significant at $5 \%$ level. In particular, one per cent increase (in nominal terms) in concentration of ownership results in labour productivity growth by $0.99 \%$. The relationship between ownership concentration and profitability follows a U-shaped pattern with the turning point at about $56 \%$. This indicates that profitability reaches 
the minimum under moderate levels of ownership concentration. For Tobins's $q$ we find a similar relationship with the turning point at about $62 \%$, but the quadratic term in the regression is only marginally significant. Thus, the result should be interpreted as negative relationship between Tobins's $q$ and concentration with some curvature rather than as true U-shaped relationship.

In the second specification, concentration is measured only among private (unrelated to the state) shareholders. The variables state and state_hold, which represent the stakes of the state and state-controlled holdings respectively, are included in regressions as control variables. Regression results are reported in Table 4.

Table 4

Concentration of private ownership and firm performance - IV estimation

\begin{tabular}{|c|c|c|c|c|c|c|}
\hline & \multicolumn{2}{|c|}{ ln (labour productivity) } & \multicolumn{2}{|c|}{ profitability } & \multicolumn{2}{|c|}{ ln (Tobins's q) } \\
\hline & Coef. & $\mathrm{z}$ & Coef. & $\mathrm{z}$ & Coef. & $\mathrm{z}$ \\
\hline conc_private & $.0085571 * *$ & 1.98 & .0008675 & 0.25 & $-.0245862 * *$ & -2.22 \\
\hline conc_private squared & & & $-8.87 \mathrm{e}-07$ & -0.03 & & \\
\hline state_hold & $.0082888 *$ & 1.93 & .000347 & 0.33 & $-.0198469^{*}$ & -1.90 \\
\hline state $^{-}$ & .0059313 & 1.45 & -.0002857 & -0.28 & $-.0179279 *$ & -1.82 \\
\hline metallurgy & .1417044 & 0.73 & $-.0651324 * *$ & -1.97 & $-.6623159 *$ & -1.93 \\
\hline machine building & $-.9716353 * * *$ & -4.86 & $-.1022345^{* * *}$ & -3.06 & $-1.318757 * * *$ & -3.77 \\
\hline oil, gas and chemicals & .3373346 & 1.55 & $-.0826957 * *$ & -2.01 & .0060217 & 0.01 \\
\hline power utilities & $.5649199 * *$ & 2.36 & -.0545669 & -1.11 & -.4241694 & -0.91 \\
\hline telecommunications & $-.7483578 * * *$ & -3.28 & .0175141 & 0.40 & $1.133473^{* *}$ & 2.46 \\
\hline size & $-2.196841 * * *$ & -3.72 & $-.2837913 * * *$ & -2.85 & $-2.517542 * *$ & -2.43 \\
\hline size_squared & $.1129603 * * *$ & 3.63 & $.0137582 * * *$ & 2.61 & $.1275072 * *$ & 2.33 \\
\hline dummy for 1996 & $-.0685764 *$ & -1.65 & .1115944 & 0.99 & $-.8080776^{* * *}$ & -4.92 \\
\hline dummy for 1997 & -.0562402 & -1.25 & .1130422 & 1.00 & $-.7185684 * * *$ & -4.32 \\
\hline inflation & & & .0015441 & 1.51 & & \\
\hline ln (RTS index) & & & & & $1.73398 * * *$ & 12.61 \\
\hline constant & $8.425751 * * *$ & 3.03 & $1.38296^{* * *}$ & 2.74 & 3.035768 & 0.62 \\
\hline Wald chi2 & 151.76 & & 119.64 & & 558.23 & \\
\hline Prob $>$ chi 2 & 0.0000 & & 0.0000 & & 0.0000 & \\
\hline
\end{tabular}

****significant at $1 \%$ level, ** significant at $5 \%$ level, * significant at $10 \%$ level

Note: The variable conc_private_squared is dropped when the coefficients on it and on the variable conc_private are both insignificant while their joint significance is not rejected at $\mathrm{p}=0.05$.

For concentration of ownership in the hands of private owners we find that it is associated with higher labour productivity, but lower Tobins's $q$. These relationships are linear. In particular, labour productivity grows by $0.86 \%$ with increase of ownership concentration by one per cent in nominal terms. There is no evidence of that profitability is affected by concentration of ownership in the hands of private shareholders. 
THE ROLE OF MAJORITY OWNERSHIP BY THE STATE

This section investigates to what extent our results are driven by large incidence of state ownership, in particular, ownership by state holdings, which is often represented by controlling blocks of shares. The interests and the behaviour of these shareholders are likely to be different from those of private legal and physical persons. When a state holding is the main shareholder in a company, the concentration of ownership in the hands of private shareholders may be of minor importance since their influence on the decision-making process within the firm is limited.

To investigate this issue we construct an additional variable conc_private_nsc, which equals the variable conc private if the state and the state holdings together do not possess a controlling block of shares in a company, and zero otherwise. The idea is that concentration of private ownership matters little if the state-related entities have the majority of votes. We include this variable in a new regression together with the variables conc_private, state_hold, and state. The estimation technique is random effects OLS. Regression results are reported in Table 5.

Table 5

Concentration of private ownership and firm performance in the presence of majority ownership by the state - OLS estimation

\begin{tabular}{|c|c|c|c|c|c|c|}
\hline & \multicolumn{2}{|c|}{ In (labour productivity) } & \multicolumn{2}{|c|}{ profitability } & \multicolumn{2}{|c|}{$\ln$ (Tobins's q) } \\
\hline & Coef. & $\mathrm{z}$ & Coef. & $\mathrm{z}$ & Coef. & $\mathrm{z}$ \\
\hline conc_private & $.0071712 *$ & 1.71 & .0013847 & 1.42 & -.0006496 & -0.08 \\
\hline conc_private_nsc & -.005918 & -1.33 & $-.0020932 * *$ & -2.02 & $-.0139561 *$ & -1.92 \\
\hline state & -.0008944 & -0.39 & $-.0016727^{*}$ & -1.83 & $-.0111817^{*}$ & -1.66 \\
\hline state_hold & $8.52 \mathrm{e}-07$ & 0.00 & -.0015097 & -1.55 & $-.014522 * *$ & -2.25 \\
\hline metallurgy & .1997949 & 1.30 & -.0535646 & -1.15 & $-.7823477 * *$ & -2.46 \\
\hline machine building & $-.9154749 * * *$ & -4.53 & $-.0913983 * *$ & -2.01 & $-1.42234 * * *$ & -3.73 \\
\hline oil, gas and chemicals & $.4994127 * * *$ & 2.82 & -.0534273 & -1.16 & -.2847853 & -0.84 \\
\hline power utilities & $.7880896 * * *$ & 4.42 & -.0080188 & -0.16 & $-.6027091 *$ & -1.69 \\
\hline telecommunications & $-.5695402 * * *$ & -2.98 & .0453344 & 0.85 & $.7595216^{* *}$ & 2.15 \\
\hline size & $-2.395532 * * *$ & -3.59 & $-.323448^{*}$ & -1.70 & $-2.261658^{*}$ & -1.93 \\
\hline size_squared & $.123823 * * *$ & 3.46 & $.0159487 *$ & 1.66 & $.1144162 *$ & 1.88 \\
\hline dummy for 1996 & -.0337427 & -0.89 & .0683065 & 1.04 & $-.7845733 * * *$ & -5.15 \\
\hline dummy for 1997 & -.0174677 & -0.45 & .0694991 & 1.10 & $-.7159598 * * *$ & -4.65 \\
\hline inflation & & & $.0011094 *$ & 1.89 & & \\
\hline ln (RTS index) & & & & & $1.64529 * * *$ & 14.03 \\
\hline constant & $9.592094 * * *$ & 3.10 & $1.674682 *$ & 1.79 & 1.901668 & 0.34 \\
\hline Wald chi2 & 150.42 & & 71.71 & & 611.92 & \\
\hline Prob $>$ chi2 & 0.0000 & & 0.0000 & & 0.0000 & \\
\hline Test for RE: chi2 (1) & 195.15 & & 126.42 & & 100.00 & \\
\hline Test for RE: Prob>chi2 & 0.0000 & & 0.0000 & & 0.0000 & \\
\hline
\end{tabular}

$* * *$ significant at $1 \%$ level, $* *$ significant at $5 \%$ level, $*$ significant at $10 \%$ level 
The variable conc_private_nsc turns out to be significant in the regressions with profitability and Tobins's $q$, while the variable conc private becomes significant in the regression with labour productivity. The regressions show that the effect of concentration of ownership in the hands of private owners on company performance is not continuous. The signs on the coefficients indicate a harmful effect of ownership concentration in the hands of private owners on profitability and Tobins's $q$ when the state and state holdings together do not have the majority of votes. Private ownership concentration also turns out to have some positive effect on labour productivity. However, the coefficients on ownership concentration are only marginally significant at $10 \%$ level in the equations with both labour productivity and Tobins's $q$.

\section{DISCUSSION OF FINDINGS}

The above results show that in the Russian context the relationship between ownership concentration and company performance is rather complex and cannot be confined to the classical theory originated from the pioneering work by Berle and Means.

Higher ownership concentration - measured either for all categories of owners or for the unrelated to the state shareholders only - is connected with higher labour productivity. This finding is expected as it is in line with theoretical arguments that more concentrated ownership results in better monitoring of managers and restrains their opportunities to pursue their own interests such as living an easy life. However, the relationships between ownership concentration on the one hand and profitability and Tobins's $q$ on the other exhibit quite different patterns that deserve special attention.

For profitability and concentration of ownership in the hands of all types of shareholders we find a $U$-shaped pattern reaching the minimum at about $56 \%$ concentration. This finding together with the earlier result for labour productivity confirm that efficiency gains (higher labour productivity) stemming from ownership concentration do not adequately materialise in higher profits. This may indicate the existence of conflicts between large and small shareholders regarding the distribution of company profits. Large shareholders may be powerful enough to appropriate the lion's share of profit themselves and to deprive small owners of their part of residual income. The more shares they have the easier they will succeed. However, the incentives of large shareholders to expropriate minority owners are likely to be a decreasing function of ownership concentration: when ownership concentration approaches $100 \%$, large owners have the legal right on almost all profit. Not surprisingly, minority shareholders' oppression peaks when 
ownership concentration is slightly above $50 \%$, which provides large owners with control over the company.

A further clue to understanding the relationship between profitability and ownership concentration can be obtained by differentiating between private shareholders and those, which are related to the state. We find no link between concentration of ownership in the hands of private owners and company profitability. However, when we consider the case of majority ownership by the state, the regression analysis shows that the concentration of private ownership is negatively related to profitability if the state-related entities do not have a controlling block of shares. The implication seems to be that private shareholders are inclined to extract private benefits of control and to expropriate minority owners but majority ownership by the state prevents such behaviour. This is consistent with evidence presented in Black et al. (2000) showing that soon after the completion of privatisation of profitable oil extraction enterprises many of them suddenly turned into loss-making firms. Thus, we find evidence that in the pre-crisis Russia majority ownership by the state played a positive role in corporate governance limiting the scope of shareholder expropriation.

Our results for Tobins's $q$ are close to what we find in the analysis of the concentration-profitability relationship. Concentration of ownership in the hands of all groups of shareholders decreases the value of companies and this relationship has some upward curvature. As in the profitability regression, this result may be interpreted as evidence of high risk of small shareholder expropriation. The fact that there is no clear U-shaped relationship similar to the one observed for profitability may stem from the costs of lower liquidity of shares under more concentrated ownership. When liquidity falls, shares are traded with a discount resulting in lower values of Tobins's $q$. We also find a negative relationship between concentration of ownership in the hands of private owners and Tobins's $q$. However, when the state has a majority of votes in a company, the negative effect of ownership concentration vanishes. This is in line with the earlier conclusion for profitability that substantial state ownership prevents large owners from extracting private benefits of control.

An interesting by-product of this study is evidence of a significant impact of size and industry affiliation of companies on their performance. This is consistent with the findings of Buck et al. (1999), which suggest that non-governance variables like the extent of crisis at the industry-level may affect the choice of enterprise strategy much stronger than ownership variables. The relationship between the size of companies and their performance is somewhat puzzling as it exhibits a U-shaped pattern with the turning point at employment of about 20,000 people. This indicates that firms of relatively small size (i.e., with several thousand employees) and gigantic companies are better performers than their "medium- sized" 
counterparts. We believe that better performance of large firms may be attributed to their economic and political power. In particular, these firms can effectively influence the government, asking for tax privileges, state order, changes in price regulations, customs fees, and other forms of support. This is in line with the McKinsey Global Institute report (1999) indicating that unequal treatment of firms by the state in taxation, energy prices, etc. may be of greater importance than the issues of corporate governance. The fact that smaller firms perform better may stem from their greater flexibility as well as the inability to engage in rent seeking, which makes efficiency improvement the only source of success. In this way of reasoning, the "medium-sized" firms perform poorly as they do not have enough opportunities to lobby their interests and lack necessary flexibility to rise efficiency shortly after privatisation.

\section{ACKNOWLEDGEMENTS}

The authors acknowledge financial and professional support from the Eurasia Foundation's Economics Education and Research Consortium - Russia Program (grant No. 98-219). We are grateful to Mark Schaffer, Eric Bergloef, David Brown, and Revold Entov for comments and helpful suggestions. All mistakes are our own.

\section{REFERENCES}

Baltagi, B. (1995): Econometric Analysis of Panel Data. Chichester: Wiley.

Barclay, M. and Holderness, C. (1989): Private Benefits from Control of Public Corporations. Journal of Financial Economics, 25.

Bergloef, E. and von Thadden, E. L. (1999): The Changing Corporate Governance Paradigm: Implications for Transition and Developing Countries. Paper presented at the annual World Bank conference on development economics, Washington, D.C.

Berle, A. and Means, G. (1932): The Modern Corporation and Private Property. New York: Macmillan.

Bevan, A., Estrin, S. and Schaffer, M. (1999): Determinants of Enterprise Performance during Transition. CERT Discussion Paper, No. 3.

Black, B., Kraakman, R. and Tarassova, A. (2000): Russian Privatisation and Corporate Governance: What Went Wrong? Stanford Law Review, 52.

Brown, D. and Earle, J. (2000): Privatization and Restructuring in Russia: New Evidence from Panel Data on Industrial Enterprises. RECEP Working Paper, No. 1.

Buck, T., Filatotchev, I., Wright, M. and Zhukov, V. (1999): Corporate Governance and Employee Ownership in an Economic Crisis: Enterprise Strategies in the Former USSR. Journal of Comparative Economics, 27.

Burkart, M., Gromb, D. and Panunzi, F. (1997): Large Shareholders, Monitoring and the Value of the Firm. Quarterly Journal of Economics, 112: 3. 
Claessens, S. and Djankov, S. (1999): Ownership Concentration and Corporate Performance in the Czech Republic. CEPR Discussion Paper, No. 2145.

Claessens, S., Djankov, S. and Pohl, G. (1996): Ownership and Corporate Governance: Evidence from the Czech Republic. World Bank Working Paper, No. 1737.

Demsetz, H. and Lehn, K. (1985): The Structure of Corporate Ownership: Causes and Consequences. Journal of Political Economy, 93.

Earle, J. S. (1998): Post-Privatisation Ownership Structure and Productivity in Russian Industrial Enterprises. Paper presented at the ACES-ASSA meetings, Chicago.

Edwards, J. and Weichenrieder, A. (1999): Ownership Concentration and Share Valuation: Evidence from Germany. CESifo Working Paper, No. 193.

Fama, E. F. and Jensen, M. (1983): Agency Problems and Residual Claims. Journal of Law and Economics, 26

Frydman, R. and Rapaczynski, A. (1994): Privatisation in Eastern Europe: Is the State Withering Away? Budapest: Central European University Press.

Hansmann, H. (1990): When Does Worker Ownership Work? ESOPs, Law Firms, Codetermination and Economic Democracy. The Yale Law Journal, 99: 8.

Holmstrom, B. and Tirole, J. (1993): Market Liquidity and Performance Monitoring. Journal of Political Economy, 101.

Jensen, M. (1997): The Modern Industrial Revolution, Exit and the Failure of Internal Control Systems. In: Studies in International Corporate Finance and Governance Systems: A Comparison of the U.S., Japan and Europe. Oxford: Oxford University Press.

Jensen, M. and Meckling, W. (1976): Theory of the Firm: Managerial Behaviour, Agency Cost and Capital Structure. Journal of Financial Economics, 3.

Kapelyushnikov, R. (2000): Krupneyshie i dominiruyushchie sobstvenniki v rossiyskoy promishlennosti: svidetelstva monitoringa REB (The Largest and Dominant Owners in Russian Industry: Evidence from REB Monitoring). Voprosy Economiki, 1.

Krueger, A. (1990): Government Failures in Development. Journal of Economic Perspectives, 4.

McConell, J. J. and Servaes, H. (1990): Additional Evidence on Equity Ownership and Corporate Value. Journal of Financial Economics, 27.

McKinsey Global Institute (1999): Unlocking Economic Growth in Russia. Moscow.

Morck, R., Shleifer, A. and Vishny, R. (1988): Management Ownership and Market Valuation: An Empirical Analysis. Journal of Financial Economics, 20.

Mundlak, Y. (1978): On the Pooling of Time Series and Cross Sectional Data. Econometrica, Vol. 46.

Perotti, E. and Gelfer, S. (1998): Investment and Financing in Russian Financial-Industrial Groups. RECEP Working Paper, No. 1.

Shapiro, C. and Willig, R. (1990): Economic Rationales for the Scope of Privatisation. In: Economy of Public Sector Reform and Privatisation. London: Westview Press.

Shleifer, A. and Vishny, R. (1994): Politicians and Firms. Quarterly Journal of Economics, 109: 4.

Shleifer, A. and Vishny, R. (1997): A Survey of Corporate Governance. Journal of Finance, 52: 2.

Stulz, R. (1988): Managerial Control of Voting Rights: Financing Policies and the Market for Corporate Control. Journal of Financial Economics, 20.

Vickers, J. and Yarrow, G. (1988): Privatisation: An Economic Analysis. Cambridge, MA: MIT Press.

$\mathrm{Xu}, \mathrm{X}$. and Wang, Y. (1997): Ownership Structure, Corporate Governance and Firm's Performance: The Case of Chinese Stock Companies. World Bank Working Paper, No. 1742.

Zeckhauser, R. and Pound, J. (1990): Are Large Shareholders Effective Monitors? An Investigation of Share Ownership and Corporate Performance. In: Hubbard, R. G. (ed.): Asymmetric Information, Corporate Finance and Investment. Chicago: University of Chicago Press. 